\title{
A Systematic Review of Field Trials to Synthesize Existing Knowledge and Agronomic Practices on Protein Crops in Europe
}

\author{
Mohamed Houssemeddine Sellami ${ }^{1, *(\mathbb{D}}$, Cataldo Pulvento ${ }^{1}\left({ }^{\circ}\right.$, Massimo Aria $^{2}{ }^{(0)}$, \\ Anna Maria Stellacci ${ }^{3}$ and Antonella Lavini ${ }^{1}$ \\ 1 National Research Council of Italy (CNR), Institute for Agricultural and Forestry Systems in the \\ Mediterranean (ISAFOM), 80056 Ercolano, Italy; cataldo.pulvento@cnr.it (C.P.); antonella.lavini@cnr.it (A.L.) \\ 2 Department of Economic and Statistics, University of Naples Federico II, 80126 Naples, Italy; aria@unina.it \\ 3 Department of Soil, Plant and Food Sciences, University of Bari Aldo Moro; 70126 Bari, Italy; \\ annamaria.stellacci@uniba.it \\ * Correspondence: hsellemi@yahoo.fr; Tel.: +39-081-788-6704
}

Received: 13 May 2019; Accepted: 1 June 2019; Published: 6 June 2019

\begin{abstract}
Protein crops can represent a sustainable answer to growing demand for high quality, protein-rich food in Europe. To better understand the state of scientific studies on protein crops, a systematic review of field trials results to collect existing knowledge and agronomic practices on protein crops in European countries was conducted using published data from the literature (1985-2017). A total of 42 publications was identified. The following seven protein crops were considered: quinoa, amaranth, pea, faba bean, lupin, chickpea, and lentil. Observations within the studies were related to one or more of eight wide categories of agronomic managements: deficit irrigation $(n=130)$, salinity $(n=6)$, tillage $(n=211)$, fertilizers $(n=146)$, sowing density $(n=32)$, sowing date $(n=92)$, weed control $(n=71)$, and multiple interventions $(n=129)$. In $86 \%$ of the studies, measures of variability for yield mean values are missing. Through a multiple correspondence analysis (MCA) based on protein crops, European environments, and agronomic management factors, we provide a state of art of studies carried out in Europe on protein crops over the 32-year period; this study will allow us to understand the aspects that can still be developed in the topic. Most investigated studies refer to southern Europe and showed some trends: (i) faba bean, pea, and lupin provide highest seed yields; (ii) sowing date, sowing density, fertilization, and deficit irrigation are the agronomic practices that most influence crop yield; (iii) studies conducted in Central Europe show highest seed yields. The output from this study can be used to guide policies for sustainable crop management.
\end{abstract}

Keywords: protein crops; systematic review; Europe; multiple correspondence analysis (MCA)

\section{Introduction}

Meeting the globally growing demand for high quality, protein-rich food, that can satisfy the need of a growing world population while considering environmental sustainability, adapted land-use practices, and food security are special challenges [1]. Europe has a large consumption of animal-based proteins for food, i.e., meat and dairy products whereas most plant protein in the European market is used as feed (for instance more than $95 \%$ in the Netherlands; [2]).

The European Union has a $70 \%$ deficit in protein-rich grains that is met primarily by imports of GMO soya for feed from USA and South America [3-5]. The deficiency in locally grown protein sources also creates price volatility and trade distortions [6]. 
Increasing the proportion of vegetable proteins and decreasing those of animal origin in the human diet is a win-win situation from both environmental and nutritional standpoints [6], but also for bio-diversity and sustainability in crop production. However, there are currently few options to encourage this. Vegetable protein sources should have high protein content, high digestibility, low anti-nutritional factor levels, high amount of essential amino acids, and be comparable in price to animal protein sources [7].

Arable land for dry pulses in the Europe, from 2007 to 2017, ranged between 1.7 and 4.2 million hectares. In recent years, this area increased considerably. In that period, an increase of $53.15 \%$ of the area harvested at Europe-level was recorded [8]. In 2017, the total harvest of dry pulses in Europe was 9.47 million tons (Figure 1). The production in 2016 was 7.43 million tons with an increase of $17.62 \%$ in comparison to 2015 . The dry pulse harvested in 2017 was $101.1 \%$ higher than the average production of 4.7 million tons registered in 2007-2016. Other high-quality protein crops like quinoa were recently introduced in Europe; the area under quinoa cultivation in Europe increased from 0 in 2008 to 5000 ha in 2015, mainly in France, Spain, and the UK [9].

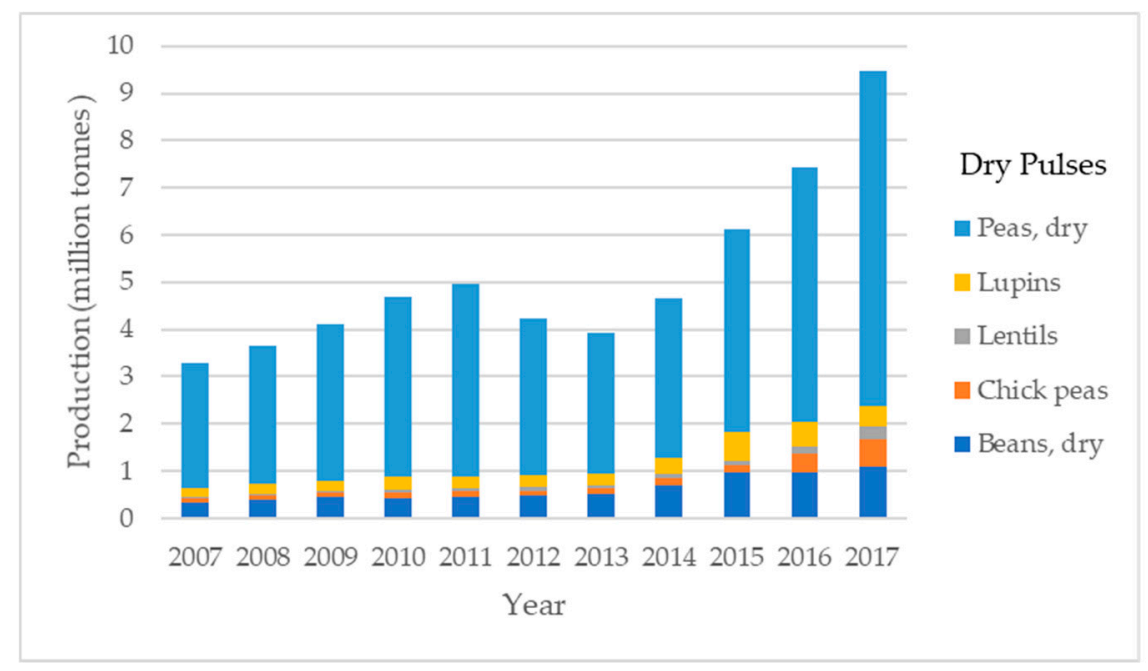

Figure 1. Evolution of harvest production (million tons) of dry pulses by species on Europe.

Producing protein crops as grain legumes is often viewed as risky by European farmers, who tend to prefer cultivating non-legume species such as cereals, oilseeds, and tubers $[10,11]$. Several authors have in fact hypothesized that a large adoption of legume crops by European farmers is hampered by frequent losses due to high inter-annual yield variability $[3,10,12]$.

The objective of this study was to evaluate, using a systematic review, the agronomic management practices in different European environments on the basis of the literature on protein crops, in order to establish the weight and the significance of the three factors (agronomic management, European environment, and protein crop) for the improvement of production and diffusion of these crops.

A systematic review (SR) of the literature provides a replicable, transparent, and reliable method of identifying, assessing, and summarizing available evidence on a research question, with reduced bias $[13,14]$.

This work is part of a European project called "Development of high-quality food protein from multi-purpose crops through optimized, sustainable production and processing methods" (PROTEIN2FOOD, AMD-635727). This project aims to provide a platform for a diverse production of protein crops throughout various EU-climate zones, supporting reduction of soybean import, and generating novel protein food products by combination of nutritious protein sources, i.e., the quality and quantity of protein from selected high protein quality seed crops (quinoa, amaranth) and legumes with high protein content (lupin, faba beans, pea, chickpea, lentil), to support the reduction of meat consumption. The positive trend will be strengthened by the development of new plant-based 
protein-rich products of high consumer acceptance, environmental sustainability, and income generation for farmers in European countries.

\section{Methods}

\subsection{Literature Research}

A systematic review (SR), across two bibliographic databases (ISI Web of Science ${ }^{\mathrm{TM}}$ and Scopus ${ }^{\mathrm{TM}}$ ) and one website search (Google Scholar), was used to identify studies exploring the agronomic practices on protein crops in European countries (we are including Turkey as European country, because it is a (founding) member of the Council of Europe, and a member of the EU Customs Union) and that were written in English, French, Spanish, and Italian (languages the authors felt competent to review) between 1985 and 2017 in peer-reviewed journals. Searches of academic databases were performed on 21 December 2017. In bibliographic databases the following search strings were used to search on 'topic words' combined with Boolean operators: (field OR cultivar* OR genotyp* OR ecotype* OR crop* OR farm* OR cultivar* OR accessions) AND (yield OR grain OR product* OR protein OR seed ${ }^{*}$ OR ((water OR nitrogen) AND use AND efficiency)) AND (europ* OR Mediterranean NOT (Tunisia OR Algeria OR Morocco OR Egypt OR Lebanon OR Libya OR Syria OR Israel OR Palestine)) AND (legum* OR amaranth* OR (peas OR (Pisum AND sativum)) OR (bean OR (Vicia AND faba)) OR (lentil OR (Lens AND culinaris)) OR (lupin* OR (Lupinus AND (albus OR mutabilis))) OR (Chickpea OR (Cicer AND arietinum)) OR (quinoa* OR (Chenopodium and quinoa)). The wildcards* represent any number of characters. Because of the large number of treatments, genotypes, and investigation areas, we used abbreviations for each variable. The complete abbreviations list can be found in the Supplementary Materials (SM) 1.

\subsection{Inclusion and Exclusion Criteria}

We used a highly robust and rational systematic review methodology to synthesize the evidence from a wide range of sources. In this study, we constrained the SR by defining boundaries to include: (I) only studies that considered food crop production in specific locations in Europe; (II) studies conducted only under field conditions, but not under glasshouse conditions and pots; and (III) studies that focused on crop productivity, omitting forestry, fisheries, livestock, and other non-food crop agricultural sectors. Following SR convention, the search terms were based on the three PIO components (population, interventions, and outcome) (Table 1) and a list of references included in the SR meta-database is provided in SM2.

Table 1. Defining the PIO terms for the research 'question' used in this study

\begin{tabular}{cc}
\hline PIO & Description \\
\hline Population & Agriculture-food crops under field conditions \\
& Crops included quinoa, amaranth, pea, faba bean, lupin, chickpea and lentil \\
Europe: Study included all the countries in the continent & irrigation, and weed control \\
Intervention & Management included sowing date, sowing density, fertilizer, tillage, salinity, deficit \\
Outcomes & Yield, yield gap, potential yield, farmer yield, and attainable yield \\
\hline
\end{tabular}

\subsection{Screening}

Following removal of duplicates, to extract yield information, data from accepted papers were entered into Endnote (online bibliographic management software) (version basic; Clarivate Analytics, https://access.clarivate.com/\#/login?app=endnote), all the references retrieved and screened for relevance using the following inclusion criteria: every study identified was screened through three stages: title, abstract, and full text. At each level, records containing or likely to contain relevant information were retained and taken to the next stage. 


\subsection{Coding and Data Extraction}

Meta-data (descriptive categorical information regarding citations, study setting, design, and methods) were extracted from included studies following full text assessment.

The treatments investigated (agronomic management) were recorded for each study as categorical variables where possible; in this case, a complete disjunctive coding of our variables (treatments investigated) was carried out. This means that variables are dichotomous, assuming value " 1 " if should the keyword be associated to the paper, and " 0 " if not. This coding was conducted according to methods described by Cuccurullo et al. [15].

Since meta-analysis considers each observation to be independent [16], data for different years or experimental conditions (i.e., cultivars or other experimental factors) within each publication were treated as independent observations. Data were obtained directly from tables and if data were provided in graphical form, means were extracted using WebPlotDigitizer [17].

\subsection{Statistical Analysis}

Multiple correspondence analysis (MCA) was performed on observations selected from literature sources analysis. The MCA is an exploratory multivariate technique used to simplify data visualization when individuals are described by categorical variables [18]. MCA allows the investigation of several qualitative parameters and permits a geometrical representation of all the information [19]. A MCA was performed to identify the overall correlation of the protein crops in the different agronomic management with environmental conditions (geographical and climatic region). To improve the quality (the total inertia) of the description provided by the MCA, an adjusted formula given by Benzécri [20] was used. This analysis was carried out using the software package FactoMineR [21] in R studio software [22].

\section{Results}

\subsection{Screening Process}

Schematic representation of the screening process is given in Figure 2. We ultimately identified and screened 2020 sources of literature (after removal of 1409 duplicates or non-journal papers), of which 42 were subsequently selected and analyzed, to provide 818 'observations'.

Our screening process reveals that accessible, published protein crop cropping systems research in European countries, of a high reporting standard suitable for this systematic review, is concentrated in the southern Europe (87\% of observations) (Table 2 and Figure 3). 

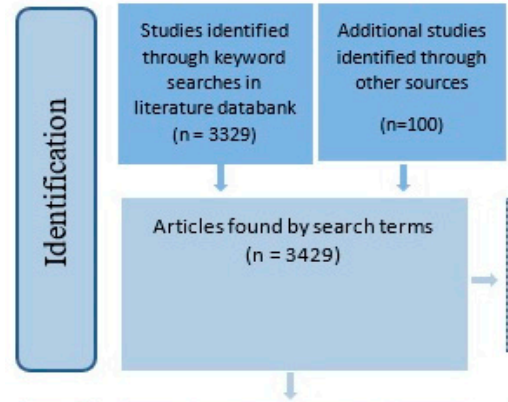

Studies excluded (Remove duplicates, non-journal papers and papers in languages other than $\mathrm{En}$, Sp, fr or It. $\quad(n=1409)$
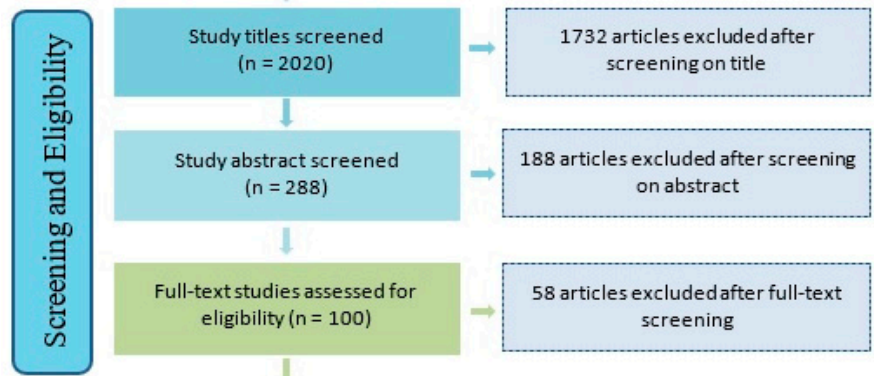

$$
\forall
$$

Full-text studies assessed for eligibility $(n=100)$

58 articles excluded after full-text $\downarrow$

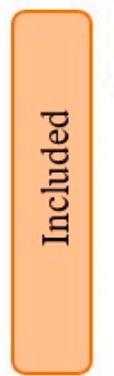

Meta-data extraction of 42 articles

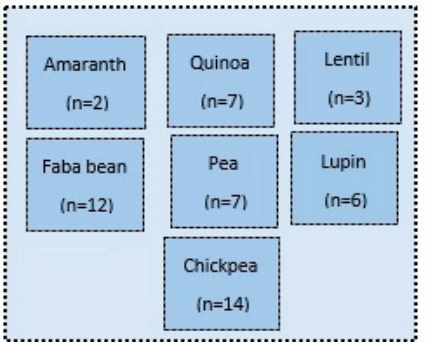

Figure 2. Selection of studies for inclusion in the systematic review (n represent the number of studies).

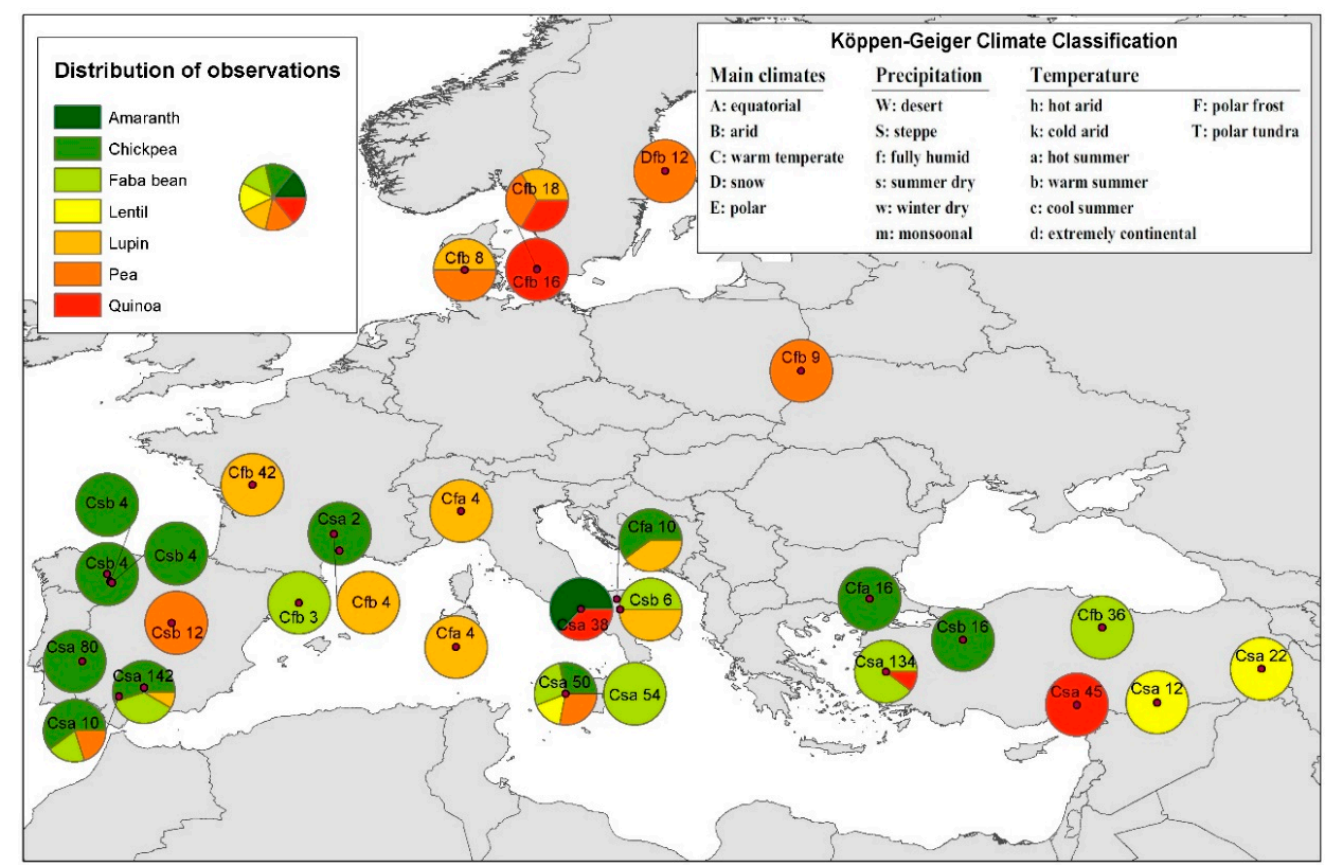

Figure 3. Distribution of doughnut chart of all observations $(n=818)$ by crops (amaranth, chickpea, faba bean, lentil, lupin, pea, and quinoa), by Köppen-Geiger climate classification zones (warm temperate climate zone (fully humid and summer dry, i.e., Cfa, Cfb, Csa, Csb, Csc); the snow climate zone (fully humid, i.e., Dfb)) and study sites on the map of Europe. The writing in each doughnut chart represents the climate classification and the total number of observations for each study area. 
Table 2. Descriptive statistical parameters (minimum, maximum, mean, median, SD and CV) relative to yield ( $t$ ha ${ }^{-1}$ ) for all crops and split into northern (NE), central (CE), and southern (SE) Europe.

\begin{tabular}{|c|c|c|c|c|c|c|c|c|c|c|c|c|}
\hline \multirow{2}{*}{$\begin{array}{l}\text { European } \\
\text { Region }\end{array}$} & \multirow{2}{*}{$\begin{array}{c}\text { No. of } \\
\text { Countries }\end{array}$} & \multirow{2}{*}{$\begin{array}{c}\text { List of } \\
\text { Countries }\end{array}$} & \multirow{2}{*}{$\begin{array}{l}\text { No. of } \\
\text { Cases }\end{array}$} & \multirow{2}{*}{$\begin{array}{c}\text { No. of } \\
\text { Observations }\end{array}$} & \multirow{2}{*}{ Crops } & \multirow{2}{*}{$\begin{array}{c}\text { No. of } \\
\text { Observations }\end{array}$} & \multicolumn{4}{|c|}{ Yield (t ha-1) } & \multirow{2}{*}{ S.D. ${ }^{1}$} & \multirow{2}{*}{ C.V. } \\
\hline & & & & & & & Minimum & Maximum & Mean & Median & & \\
\hline \multirow{3}{*}{$\begin{array}{c}\text { Northern } \\
\text { Europe (NE) }\end{array}$} & \multirow{3}{*}{2} & \multirow{3}{*}{$\begin{array}{l}\text { Sweden, } \\
\text { Denmark }\end{array}$} & \multirow{3}{*}{4} & \multirow{3}{*}{54} & Lupin & 10 & 0.98 & 3.95 & 2.83 & 2.96 & 1.03 & 36.18 \\
\hline & & & & & Peas & 22 & 2.36 & 6.64 & 3.87 & 3.72 & 1.18 & 30.39 \\
\hline & & & & & Quinoa & 22 & 1.54 & 2.27 & 1.82 & 1.76 & 0.21 & 11.42 \\
\hline \multirow{3}{*}{$\begin{array}{c}\text { Central } \\
\text { Europe }(\mathrm{CE})\end{array}$} & \multirow{3}{*}{2} & \multirow{3}{*}{$\begin{array}{l}\text { France, } \\
\text { Poland }\end{array}$} & \multirow{3}{*}{4} & \multirow{3}{*}{57} & Chickpea & 2 & 2.86 & 3.18 & 3.02 & 3.02 & 0.23 & 7.49 \\
\hline & & & & & Lupin & 46 & 2.15 & 4.67 & 3.51 & 3.44 & 0.58 & 16.47 \\
\hline & & & & & Peas & 9 & 2.08 & 5.03 & 3.55 & 3.89 & 0.94 & 26.51 \\
\hline \multirow{6}{*}{$\begin{array}{c}\text { Southern } \\
\text { Europe (SE) }\end{array}$} & \multirow{6}{*}{5} & \multirow{6}{*}{$\begin{array}{c}\text { Portugal, } \\
\text { Spain, } \\
\text { Italy, } \\
\text { Greece, } \\
\text { Turkey }\end{array}$} & \multirow{6}{*}{34} & \multirow{6}{*}{707} & Chickpea & 228 & 0.26 & 3.65 & 1.63 & 1.59 & 0.72 & 44.33 \\
\hline & & & & & Faba bean & 284 & 0.01 & 8.29 & 3.36 & 2.98 & 1.77 & 52.63 \\
\hline & & & & & Lentil & 42 & 0.01 & 2.18 & 0.78 & 0.73 & 0.60 & 77.32 \\
\hline & & & & & Lupin & 28 & 0.64 & 3.99 & 2.20 & 1.78 & 1.18 & 53.45 \\
\hline & & & & & Peas & 28 & 0.08 & 4.94 & 2.32 & 2.50 & 1.28 & 54.92 \\
\hline & & & & & Quinoa & 73 & 0.87 & 3.31 & 2.11 & 1.95 & 0.56 & 26.54 \\
\hline
\end{tabular}




\subsection{Geographical Distribution of Observations}

Studies were reported from nine countries (Figure 3). In the following text, numbers in brackets indicate the number of individual observations in the categories described. Southern Europe $(n=706)$ was the most frequently studied region, with Italy $(n=166)$, Portugal $(n=80)$, Spain $(n=179)$, and Turkey $(n=265)$ being the most frequently studied countries.

The most commonly studied climate zones were $\mathrm{Cfb}(\mathrm{n}=136)$ with a marine mild climate with no dry season and warm summer and Csa $(n=589)$ with a warm temperate climate with dry and hot summer (Table 3).

Table 3. Number of observations included in the meta-dataset per Köppen-Geiger climate zone

\begin{tabular}{ccc}
\hline Köppen-Geiger Climate Zone & Name of the Climate Zone & No. of Observations \\
\hline Cfa & Cfa-Humid subtropical & 34 \\
Cfb & Cfb-Marin-mild winter & 136 \\
Csa & Csa-Interior mediterranean & 589 \\
Csb & Csb-Coastal mediterranean & 46 \\
Dfb & Dfb-Humid continental mild summer, wet all year & 12 \\
\hline
\end{tabular}

The most commonly studied crops were Faba bean $(n=284)$ and Chickpea $(n=230)($ Table 2).

\subsection{Management, Date, and Duration of Trials}

Eight main groups of treatments were identified during the screening: deficit irrigation (Treatment $A$; $n=130$ ), salinity (Treatment $B ; n=6$ ), tillage (Treatment $C ; n=211$ ), fertilization (Treatment $D ; n=146$ ), sowing density (Treatment $E ; n=32$ ), sowing date (Treatment F; $n=92$ ), weed control (Treatment $G$; $\mathrm{n}=71$ ) and multiple interventions (Treatment $\mathrm{AB} / \mathrm{AD} / \mathrm{CD} / \mathrm{EF} ; \mathrm{n}=129$ ). The number of studies reporting investigations of each group of treatments is shown in Figure 4.

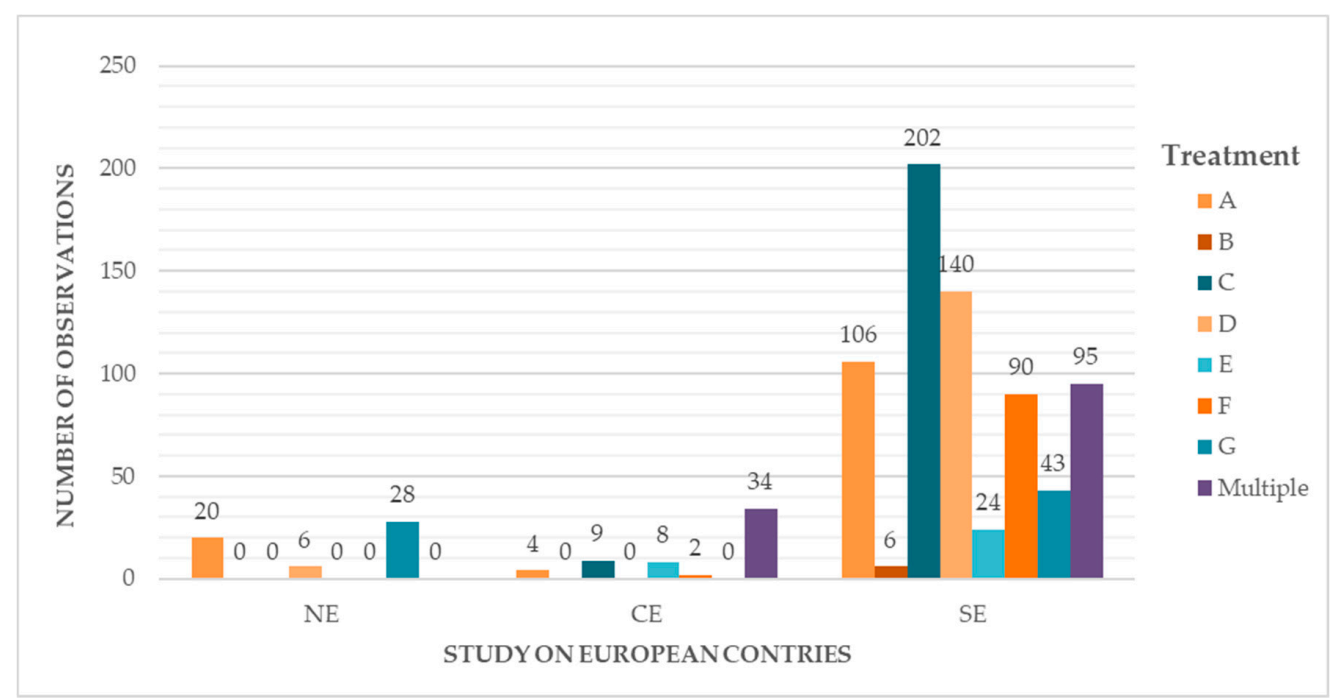

Figure 4. Number of studies undertaken across European countries. Numbers are separated by intervention group (treatment) investigated within each study. Studies may be present in more than one intervention category.

Treatment C ( $n=202)$, Treatment $D(n=140)$, Treatment A $(n=106)$, and Treatment F $(n=90)$ were the most frequently studied treatments on southern Europe (SE). On northern Europe (NE) both Treatment $A(n=20)$ and $G(n=28)$ were the most frequently studied treatments and on central Europe (CE) we found only multiple interventions (e.g., Treatment EF) with 34 observations (data not shown).

A large number of studies was carried out over a 2-year period $(n=438), 136$ for 1 year, 45 for 3 years, and 198 for more than 3 years (data not shown). 
Forty-two papers were identified through cross-referencing dating from 1984 to 2014. An evident increase in the number of observations started after 1998. The peaks occurred in 2005 and 2010, while after 2010 there was a high drop in observations (data not shown). The longest-term studies occurred in southern Europe (18 years) in Italy [23] and in Spain (11-12 years; [24,25]).

Out of the 42 studies, 36 failed to report some critical information of measures of variability for yield mean values (e.g., standard deviation, standard error, and confidence intervals) and 18 observations failed to report the start year of treatment.

\subsection{Distribution Frequencies of Yield}

The descriptive statistical parameters, relative to yield $\left(\mathrm{t} \mathrm{ha}^{-1}\right)$ for all crops and European regions, are shown in Table 2.

For northern Europe, most data were related to quinoa and pea $(n=22)$ with observations available from studies conducted in two countries in the region (Sweden, Denmark). In contrast, there was very limited published data on lupin $(\mathrm{n}=10)$ and none for amaranth, chickpea, faba bean, and lentil. The average yields for pea and lupin were 3.87 and $2.83 \mathrm{t} \mathrm{ha}^{-1}$, respectively.

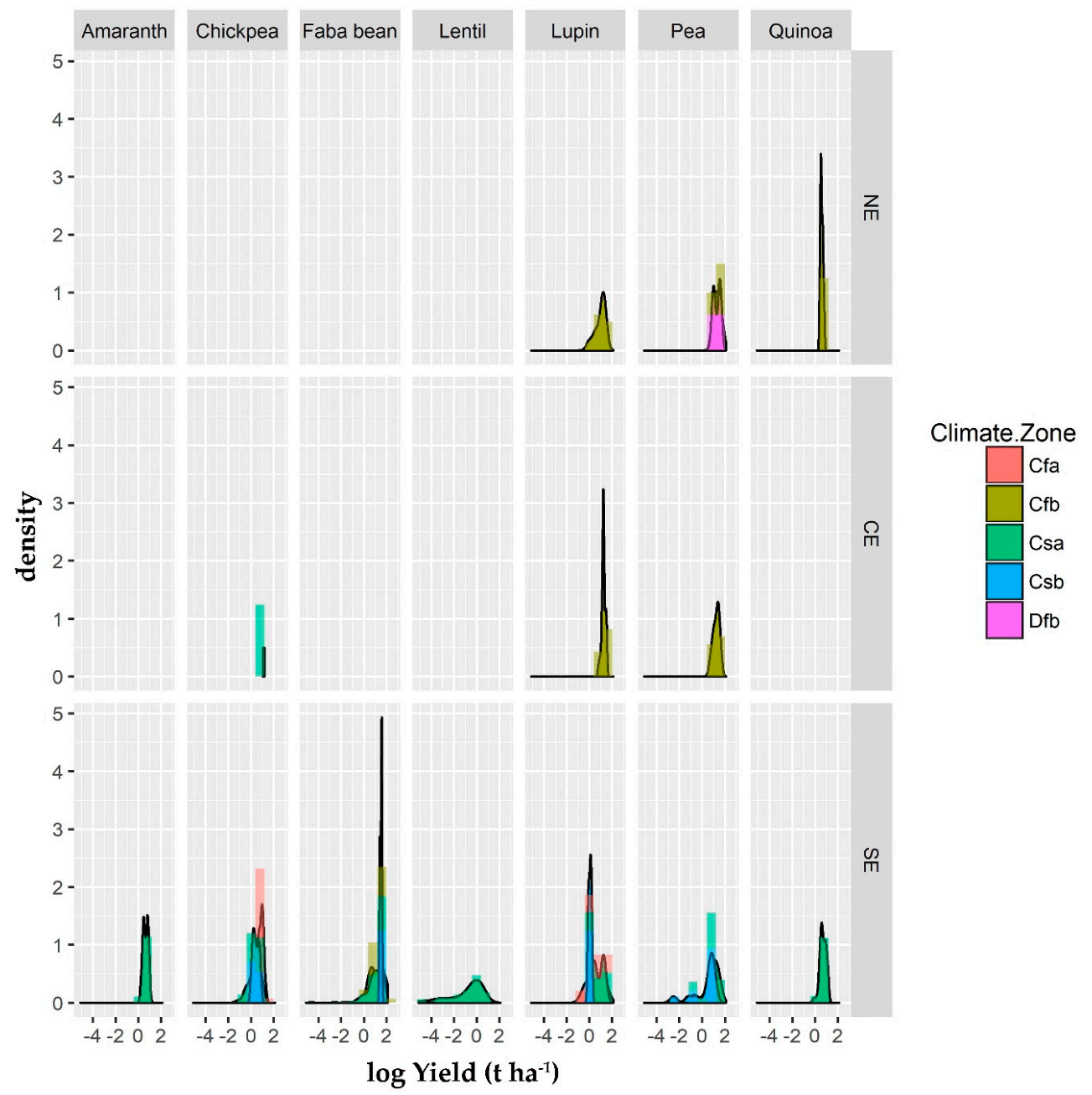

Figure 5. Distribution frequencies of $\log$ yield $\left(\mathrm{tha}^{-1}\right)$ for all observations $(\mathrm{n}=817)$ by crops (amaranth, chickpea, faba bean, lentil, lupin, pea, and quinoa) and European regions (northern (NE), central (CE), and southern (SE)) grouped by climate zone (Cfa: Humid subtropical; Cfb: Marin-mild winter; Csa: interior Mediterranean; Csb coastal Mediterranean; Dfb: humid continental mild summer, wet all year).

For central Europe, the average yield was relatively constant for different crops (chickpea, lupin, and pea). Lupin accounted for the largest number of observations $(n=46)$. Average yield in central 
Europe for lupin and pea was similar to yields found in northern Europe, and higher than that observed in Southern Europe.

In Southern Europe, there were many different crops of our study $(n=706)$ with observations available from studies conducted in five countries of the region. Average yields varied from $0.78 \mathrm{tha}^{-1}$ for lentil to $3.36 \mathrm{t} \mathrm{ha}^{-1}$ for faba bean.

The Figure 5 shows that most of the yield observations was found in the south of Europe where all species were present. The plots convey the left skewness in the major part of the yield distributions for all crops, disaggregated into European regions.

\subsection{Overall Yield across Factors of Variation}

Figure 6 shows that the variation of yield due to environment, agronomic management, and crop factors was quite large.

Response yield varied across the five climatic zones classes with yield values for Dfb and Cfb ranging from 2.47 to $4.90 \mathrm{t} \mathrm{ha}^{-1}$ and 0.98 to $8.29 \mathrm{t} \mathrm{ha}^{-1}$, respectively, with a higher percentage of values being below 4.9 and $3.9 \mathrm{t} \mathrm{ha}^{-1}$, respectively (Figure 6a). In contrast, values of yield ranged from 0.64 to $3.99 \mathrm{t} \mathrm{ha}^{-1}$, from 0.01 to $6.86 \mathrm{t} \mathrm{ha}^{-1}$ and from 0.08 to $4.87 \mathrm{t} \mathrm{ha}^{-1}$ for Cfa, Csa, and Csb, respectively. These results provide strong evidence to suggest that among the five climatic zones categories, Dfb and $\mathrm{Cfb}$ were the most productive climatic zones for all protein-crops.

Furthermore, this study found that the whisker values (the maximum and minimum values are displayed with vertical lines connecting the points to the center box) in the boxplot of the three-geographic zone categories can evaluate how yield variation is apportioned. Studies conducted in Northern Europe (NE) and Southern Europe (SE) showed the lowest yields which ranged from 0.98 to $6.64 \mathrm{tha}^{-1}$, and 0.01 to $8.29 \mathrm{tha}^{-1}$, respectively (Figure $6 \mathrm{~d}$ ). In contrast, values of yield ranged from 2.08 to $5.03 \mathrm{t} \mathrm{ha}^{-1}$ for central Europe (CE).

On the other hand, the variation of yield between protein-crops showed that faba bean, pea, and lupin were the most productive crops, with a higher percentage of values being below 4.9, 4.1 and $3.7 \mathrm{tha}^{-1}$, respectively, and lentil the least one, with a higher percentage of values being below $1.2 \mathrm{tha}^{-1}$ (Figure 6b).

Figure $6 \mathrm{c}$ shows the yield variation between different agronomic management. Treatments AD, D, $\mathrm{E}, \mathrm{EF}$, and $\mathrm{F}$ were the agronomic interventions most affecting productive response and Treatment $\mathrm{CD}$ was the least one, with yield values ranging from 1.04 to $1.8 \mathrm{t} \mathrm{ha}^{-1}$ and with a higher percentage of values being below $1.2 \mathrm{tha}^{-1}$.

\subsection{Multiple Correspondence Analysis}

To obtain a comprehensive view on the protein crop yield variation that occurred in the 44 cultivars, 8 ecotypes, 1 accession, and 14 genotypes as affected by climatic zone, geographic region, and agronomic management, the whole data set (categorical variables (column labels): protein crops, climatic zone, geographic region, and agronomic management); observations (row labels)) was subjected to multiple correspondence analysis (MCA). The first three dimensions components (dim.) explained $56.24 \%$ of the cumulative variance for our dataset, with Dim1 accounting for $27.91 \%$, Dim2 for $16.30 \%$, and Dim3 for $12.03 \%$ (Table 4). The loading plots (Figure 7) show the graphic display of the contribution and the cluster of variables on the plane defined by the two first axes of the analysis.

Table 4. Eigenvalues, relative and cumulative percentage of total variance for systematic review meta-database with respect to the three-dimension components (Dim1, Dim2, and Dim3)

\begin{tabular}{|c|c|c|c|}
\hline Dimension Components & $\operatorname{Dim} 1$ & Dim2 & Dim3 \\
\hline Eigenvalue & 0.741 & 0.566 & 0.486 \\
\hline Relative variance $(\%)$ * & 27.91 & 16.30 & 12.03 \\
\hline Cumulative variance (\%) & 27.91 & 44.21 & 56.24 \\
\hline
\end{tabular}

* Benzécri correction (1973). 


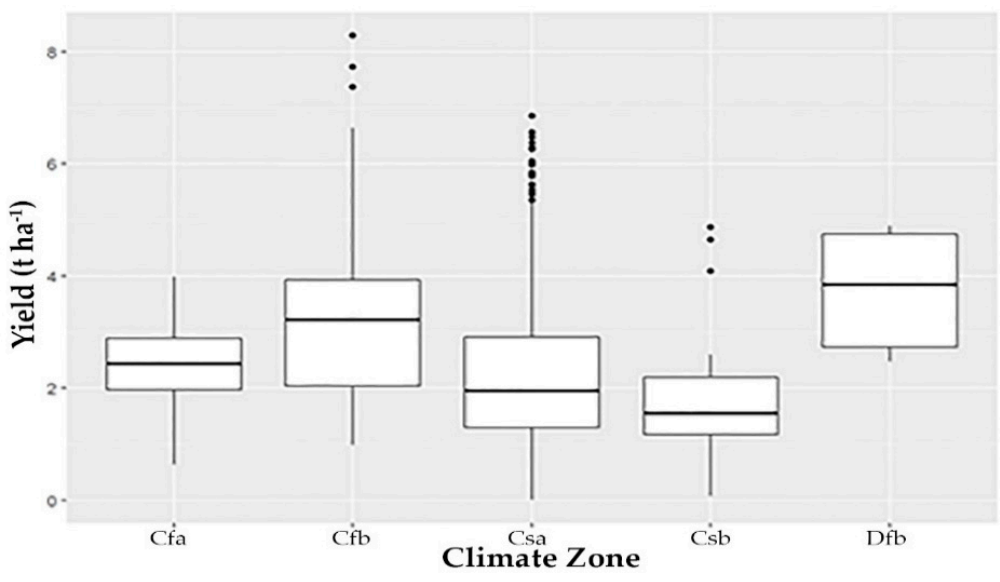

(a)

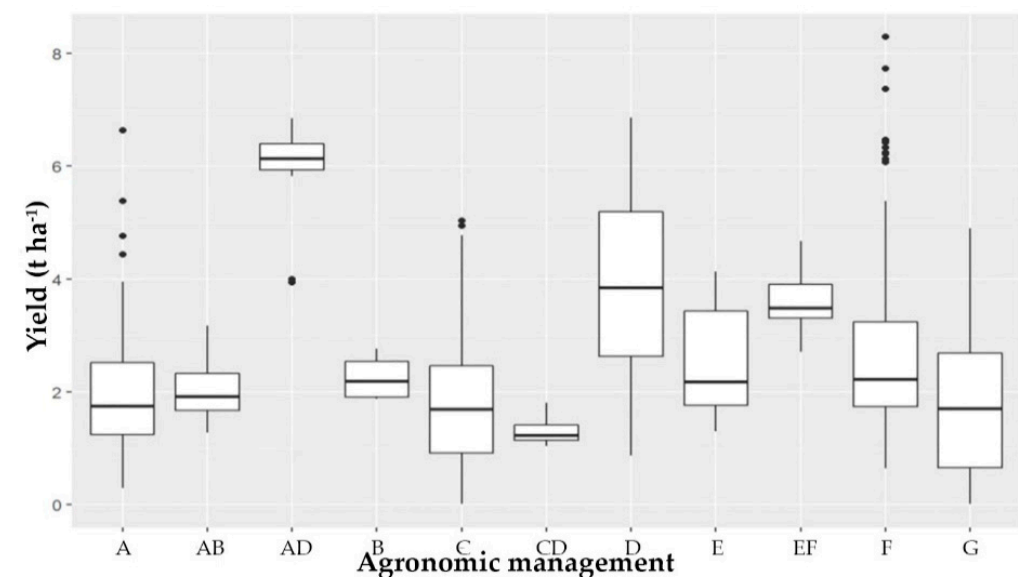

(c)

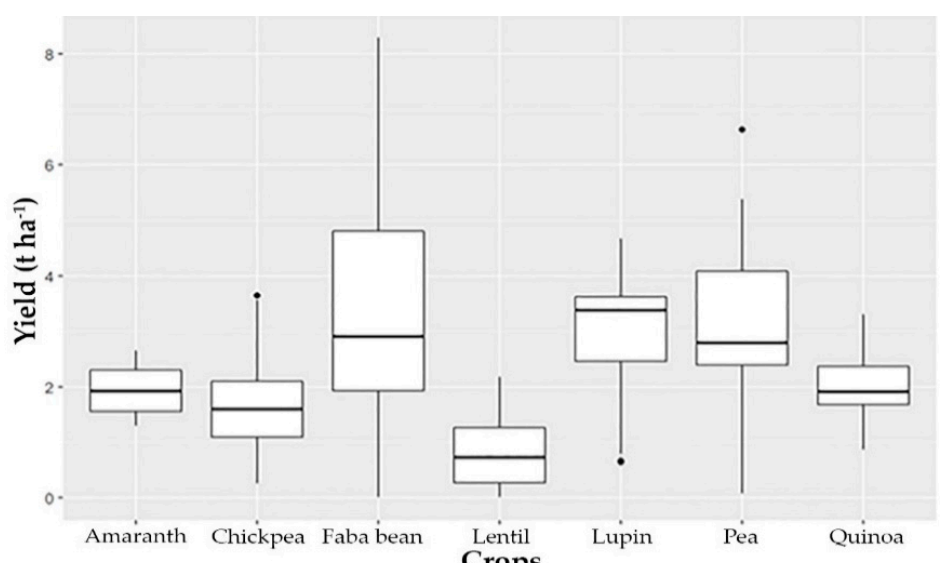

(b)

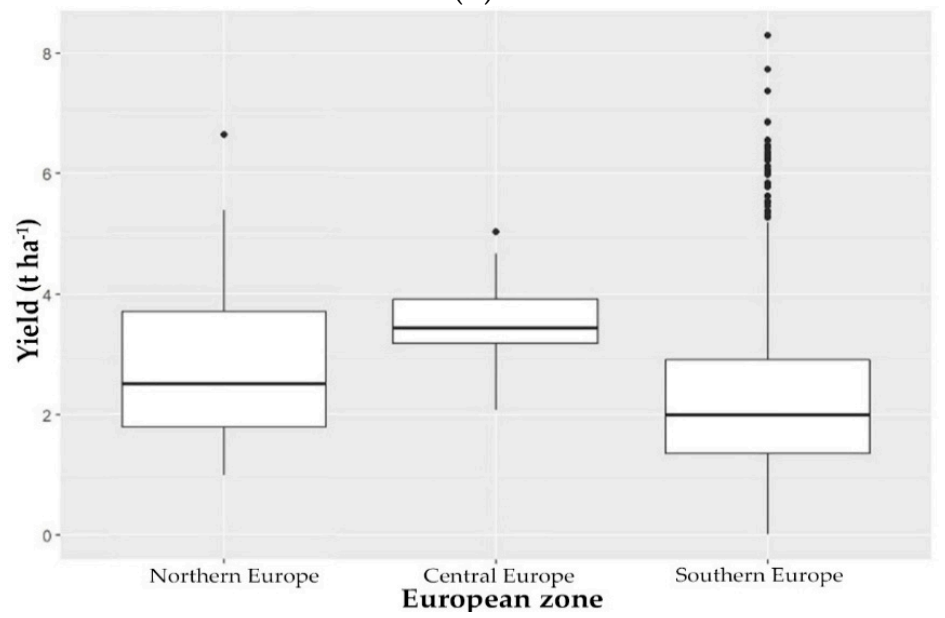

(d)

Figure 6. Box-plots of patterns of yield $\left(t \mathrm{th}^{-1}\right)$ for all observations $(\mathrm{n}=818)$ across: (a) different groups of climatic zones, Cfa: humid subtropical; $\mathrm{Cfb}$ : Marin-mild winter; Csa: interior Mediterranean; Csb: coastal Mediterranean:; Dfb: humid continental mild summer, wet all year (b) different group of Crops, (c) different groups of agronomic management A: deficit irrigation; AB: deficit irrigation and salinity; AD: deficit irrigation and fertilizer; B: salinity; C: tillage; CD: tillage and fertilizer; D: fertilizer; E: sowing density; EF: sowing density and sowing date; F: sowing date; G: weed control; and (d) different groups of European zone. Box edges represent the upper and lower quantile with median value shown in the middle of the box. The small circles on the boxplot relate to outliers. 


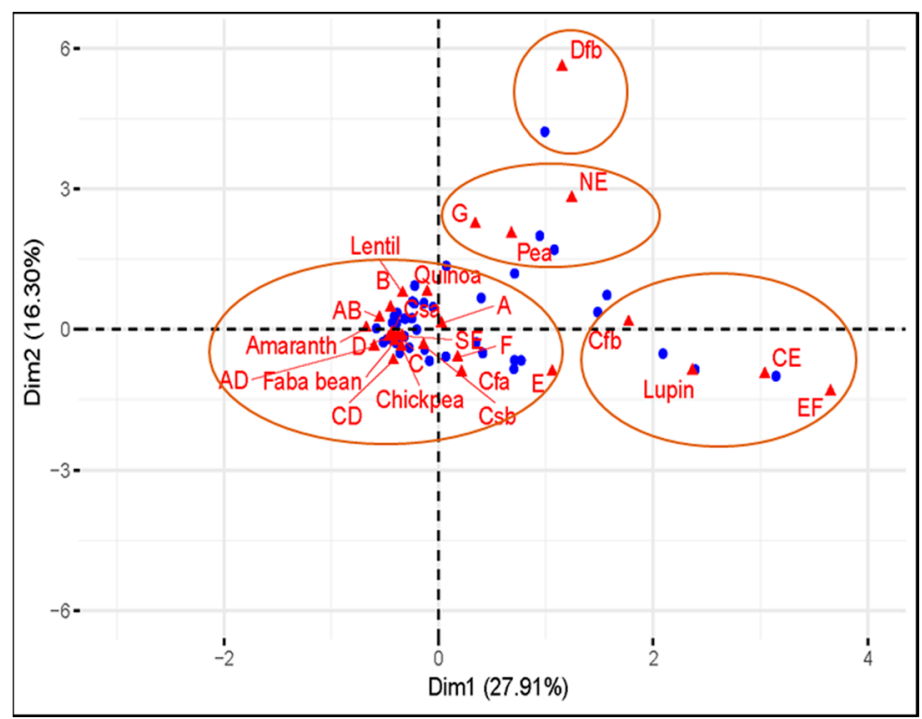

Figure 7. Multiple correspondence analysis plot of protein crops, European environments, and agronomic management factors induced by the first two dimensions components. Protein crops (quinoa, amaranth, pea, faba bean, lupin, chickpea, and lentil), European environments (geographic and climatic zones), and agronomic management (different agronomic practices) are plotted on the two first axes. Rows (observations) are represented by blue points and columns (categorical variables) by red triangles. Orange ellipses indicate different clusters analyzed.

Interpretation of correspondence analysis graphs is based on the distance between such proximate categorical variables (column labels: protein crops, climatic zone, geographic region, and agronomic management) or observations (row labels) to the origin of axes (the larger, the more significant). However, if we want to compare a row label to a column label, we need to:

1. Look at the length of the line connecting the row label to the origin. Longer lines indicate that the row label is highly associated with some of the column labels (i.e., it has at least one high residual).

2. Look at the length of the label connecting the column label to the origin. Longer lines again indicate a high association between the column label and one or more row labels.

3. Look at the angle formed between these two lines. Really small angles indicate association. $90^{\circ}$ angles indicate no relationship. Angles near $180^{\circ}$ indicate negative associations.

To interpret each axis (factor), it is necessary to consider different indicators, as absolute and relative contributions of each variable category. The former measures the extent to which one modality variable contributes to the determination of a specific factor. The latter is instead a quality indicator as it measures how much each factor contributes to the reproduction of the variable dispersion (Table 5). Particularly, we interpreted each factor considering categorical variables with a high absolute and relative contribution [15].

This path is mostly accounted for by the first (horizontal) axis and is strongly related to climatic zone (cfb) and positively correlated to agronomic management interaction (EF), geographic region (CE), and protein crops (Lupin). The second (vertical) axis was positively correlated to climatic zone $(\mathrm{dfb})$, agronomic management $(\mathrm{G})$, geographic region (NE), and protein crops (Pea) (Figure 7, Table 5).

The proximity between observations corresponds to shared-substance: observations are close to each other because a large proportion of articles treat the same search terms together; they are distant from each other when only a small fraction of articles discusses these search terms together. For example, the variables ' $C E$ ' and ' $G$ ' are far from each other, because no articles of central Europe discuss the $\mathrm{G}$ treatment.

Figure 7 shows that the most of observations has a large number of articles associated to agriculture management $(A, A B, A D, B, C, C D, D, E$, and $F)$ and climatic zone (Csa, Csb, and Cfa) related to the 
southern Europe region. This information tells us that studies from southern Europe region represent the center of the research field and tend to resemble each other.

The partitioning in four clusters is represented on the map produced by the first two principal components (Figure 7). The graph shows that the four clusters are well-separated on the first two principal components.

Table 5. Contribution and value test of different sub categorical variables for systematic review meta-database with respect to the three-dimension components (Dim1 and Dim2 and Dim3).

\begin{tabular}{|c|c|c|c|c|c|c|c|}
\hline \multicolumn{2}{|c|}{ Principal Components } & \multicolumn{2}{|c|}{ Dim1 } & \multicolumn{2}{|c|}{ Dim2 } & \multicolumn{2}{|c|}{ Dim3 } \\
\hline $\begin{array}{l}\text { Categorical } \\
\text { variables }\end{array}$ & $\begin{array}{l}\text { Variables } \\
\text { attributes }\end{array}$ & $\begin{array}{c}\text { Abs. } \\
\text { Contr. }^{a}\end{array}$ & V-Test ${ }^{b}$ & $\begin{array}{c}\text { Abs. } \\
\text { Contr. }^{\text {a }}\end{array}$ & V-Test & $\begin{array}{c}\text { Abs. } \\
\text { Contr. }^{\text {a }}\end{array}$ & V-Test \\
\hline \multirow{7}{*}{ Protein crops } & Amaranth & 0.45 & -3.35 & 0.001 & 0.15 & 7.66 & -11.19 \\
\hline & Chickpea & 1.15 & -6.22 & 1.66 & -6.54 & 2.74 & 16.78 \\
\hline & Faba bean & 1.95 & -8.51 & 0.98 & -5.27 & 1.93 & -6.86 \\
\hline & Lentil & 0.20 & -2.24 & 1.36 & 5.15 & 0.01 & 0.41 \\
\hline & Lupin & 19.17 & 22.72 & 3.49 & -8.47 & 0.06 & -1.03 \\
\hline & Pea & 1.12 & 5.40 & 13.22 & 16.23 & 3.40 & 7.62 \\
\hline & Quinoa & 0.05 & -1.11 & 3.26 & 8.25 & 9.30 & -12.93 \\
\hline \multirow{3}{*}{$\begin{array}{l}\text { European } \\
\text { countries }\end{array}$} & Northern Europe & 3.43 & 9.43 & 22.96 & 21.32 & 0.13 & 1.50 \\
\hline & Central Europe & 21.75 & 23.78 & 2.79 & -7.45 & 0.63 & -3.28 \\
\hline & Southern Europe & 3.38 & -24.52 & 0.72 & -9.92 & 0.02 & 1.36 \\
\hline \multirow{5}{*}{ Climatic zone } & $\mathrm{Cfa}$ & 0.06 & 1.27 & 1.53 & -5.44 & 2.72 & 6.71 \\
\hline & $\mathrm{Cfb}$ & 17.60 & 22.60 & 0.18 & 1.99 & 0.50 & -3.07 \\
\hline & Csa & 4.57 & -19.90 & 0.16 & -3.27 & 1.93 & -10.48 \\
\hline & Csb & 0.04 & -0.99 & 0.28 & -2.34 & 17.23 & 17.03 \\
\hline & $\mathrm{Dfb}$ & 0.66 & 4.01 & 20.34 & 19.54 & 1.45 & 4.83 \\
\hline \multirow{11}{*}{$\begin{array}{l}\text { Agronomic } \\
\text { management }\end{array}$} & A & 0.003 & 0.31 & 0.12 & 1.59 & 2.07 & 6.26 \\
\hline & $\mathrm{AB}$ & 0.84 & -4.71 & 0.22 & 2.11 & 15.55 & -16.40 \\
\hline & $\mathrm{AD}$ & 0.18 & -2.10 & 0.09 & -1.27 & 0.24 & -1.99 \\
\hline & B & 0.05 & -1.10 & 0.07 & 1.14 & 0.90 & -3.79 \\
\hline & C & 1.25 & -6.40 & 0.19 & -2.17 & 0.63 & 3.67 \\
\hline & $\mathrm{CD}$ & 0.12 & -1.71 & 0.38 & -2.68 & 12.98 & 14.50 \\
\hline & $\mathrm{D}$ & 1.31 & -6.21 & 0.22 & -2.23 & 3.03 & -7.65 \\
\hline & $\mathrm{E}$ & 1.48 & 6.11 & 1.41 & -5.21 & 2.09 & 5.86 \\
\hline & $\mathrm{EF}$ & 18.73 & 21.74 & 3.23 & -7.90 & 1.41 & -4.83 \\
\hline & $\mathrm{F}$ & 0.12 & 1.80 & 1.78 & -6.09 & 1.30 & 4.81 \\
\hline & G & 0.34 & 3.00 & 19.37 & 19.80 & 0.11 & 1.38 \\
\hline
\end{tabular}

Boldface contributions indicate the most relevant characters for each dimension component. Different climatic zones: Cfa: humid subtropical; Cfb: Marin-mild winter; Csa: interior Mediterranean; Csb coastal Mediterranean; $\mathrm{Dfb}$ : humid continental mild summer, wet all year, different group of agronomic management A: deficit irrigation; AB: deficit irrigation and salinity; AD: deficit irrigation and fertilizer; B: salinity; C: tillage; CD: tillage and fertilizer; D: fertilizer; E: sowing density; EF: sowing density and sowing date; F: sowing date; G: weed control; ${ }^{a}$ Absolute contribution, ${ }^{\mathrm{b}}$ Value test: V-test statistic asymptotically follows a standard gaussian distribution, a value below -1.96 or above 1.96 indicates that the category has a coordinate significantly different to 0 and each category has positive or negative value for each dimension.

\section{Discussion}

The area of protein crops in Europe declined almost continuously over the last five decades, from 5.8 million ha in 1961 (4.7\% of the arable area), when recording began, to 2.0 million ha in 2014 (1.6\% of the arable area) [26]. A major underlying driver behind the reduction in the proportion of arable land used for protein crops is the increased comparative advantage in the production of starch-rich cereals in Europe over the production of protein-rich grain legumes [27].

Protein crops may produce high-quality protein for food and feed, increasing soil fertility and yields in subsequent crops, potentially reducing greenhouse gas emissions and supporting biodiversity [27]. However, there are several reasons why farmers may be hesitant to grow them: the quality and quantity of the yield, and thus the financial return, vary depending on the region and weather conditions [28]. 


\subsection{European Environments}

According to Reckling et al. [29], especially in the north of Europe, where all grain legumes are spring-sown, they have generally more unstable yield than those of autumn-sown crops, because they can be constrained by water deficits during crop establishment and subsequent growth stages. Winter crops are instead established in autumn and regrow quickly after winter without any delays due to soil tillage and seedbed preparation that can also reduce soil moisture. Another factor that can contribute to yield instability in grain legumes is the indeterminate growth habit that allows the crop to respond to good conditions such as high-water availability and adequate temperature or to stop growing and reproducing under poor conditions [30]. Differently from legumes, cereals can compensate in conditions of sufficient or insufficient water and nutrient supply through modifications in tillering and flower initiation. Finally, the symbiotic nitrogen fixation affects yield and can be reduced or fail in poor conditions resulting in greater yield instability.

According to De Visser [31], the large diversity of pedoclimatic conditions all over Europe, and also the different end user needs (food, feed/ruminants, feed/monogastrics), determine which protein crops are most easily adopted. Therefore, most of the published cropping systems studies in Europe, with a high reporting standard suitable for a SR, are concentrated in Southern Europe; perhaps because the manufacturers do not consider these protein crops as having enough of a market to justify investing in research and development in all European countries.

The most commonly studied climate zones for protein crop cultivation were geographical areas with a marine mild climate with no dry season and warm summer ( $\mathrm{Cfb}$ ) - most of them in Demark, France, and Poland-and areas with a warm temperate climate with dry and hot summer (Csa) especially in southern Europe. According to Malezieux et al. [32], in some parts of Europe where winters are not severe, autumn-sown grain legumes can be grown. In Mediterranean regions, grain legumes, such as pea, are grown as a cool-season crop harvested before summer drought, or before planting an irrigated, warm-season crop such as maize.

\subsection{Protein Crops}

The most commonly studied crops were faba bean and chickpea. Beans are preferred by arable farmers because this crop is easier to grow, and has more steady yield levels [7].

The most important parameters to be considered by growers are straw height, earliness of ripening, disease resistance, and yield. Earliness of ripening is important in particular, under North European conditions to anticipate harvest and avoid cooler weather when drying of the crop in the field is slow [33].

In our review, we have focused on yield, as it is the most important parameter, but there is still lack of knowledge concerning protein content in Europe.

In south of Europe, studies on lentil, lupin, and faba bean showed the most variable yields with a coefficient of variation (CV) value of $77 \%, 54 \%$, and $53 \%$ respectively (Table 2), indicating that broad-leaved crops indeed have more unstable yields than cereals [27]. In the south, average yield was $0.78 \mathrm{t} \mathrm{ha}^{-1}$ for lentil and $3.36 \mathrm{t} \mathrm{ha}^{-1}$ for faba bean. Highest yields were identified for pea and lupin in northern Europe. For central Europe, the average yield was relatively constant for different crops (chickpea, lupin, and pea).

The variation of yield between protein crops showed that faba bean, pea, and lupin were the most productive crops, and lentil the lowest yielding.

At the European scale, the yield levels of field broad beans seem to be showing much potential in North West Europe [34] and the yield level of field peas is high, while lupins yield are considerably lower and consequently lupin crops are considered less attractive [7].

White lupin (Lupinus albus L.), yellow lupin (L. luteus L.), and narrow-leaved lupin (L. angustifolius L.), are native European legumes with a seed protein content high (up to 44\%) [35]. Lupin is mainly cultivated in North and Central Europe [36], but the results from this study show that 
it could be cultivated also in south European countries. Lupin was cultivated in ancient times but is currently neglected [37].

Among the grain legume species, peas are the main grain legume produced in Europe: they can be grown almost anywhere [34]. Their high yield potential makes profitable use of fertile soils, most of the new varieties are easy to harvest, and peas can be used for several purposes [7].

There is a large variation in yield across Europe and across the different protein crops. Protein crops suffer from yield instability compared to cereals or rapeseeds, and yield fluctuations are one of the main reasons farmers give for not growing these crops [10]. The latter is a major obstacle in further expansion and a main target for improving protein crop production. According to Stoddard et al. [38], a lack of breeding resources (indeterminate growth habit, stress resistance, etc.) and knowledge gaps (low agronomic expertise, insufficient cooperation between farmers and other actors, etc.) are responsible for the fact that only $1.6 \%$ of EU arable land is currently used for legumes, despite their agronomic and environmental benefits.

\subsection{Agronomic Managements}

Recent studies outline a comparative lack of breeding investment in Europe to improve protein crops adaptation to local agroclimatic conditions and management techniques [12,39,40], such as crop protection or density and plant spacing, irrigation, tillage, fertilization, and harvesting techniques [41-43]. It is important to highlight that a general lack of specific agronomic references to manage protein crops may be a barrier for farmers cultivating these crops in Europe [44].

In our SR, tillage $(n=211)$, fertilizer $(n=146)$, deficit irrigation $(n=130)$, sowing density, and sowing date (both the last treatments $n=158$ ) were the most productive agronomic management for protein crops in European countries.

According to Christopher and Lal [45], the cultivation and cropping may cause significant soil organic carbon (SOC) losses through decomposition of humus. The shift from pasture to cropping systems can lead to loss of soil C stocks between 25 and 43 percent [46]. Furthermore, the EU's agricultural policy has rewarded a wider range of options to increase soil carbon [47].

There is a general agreement on the influence of grain legumes on the properties of rhizosphere in terms of N supply, SOC, and P availability [48], the extent of the impact varied across legume species, soil properties, and climate conditions.

The soil type is the main determinant of plant growth, nutrient dynamics of the rhizosphere and microbial community structure. The depletion and accumulation of some macro- and micronutrients also differed between crop systems (i.e., monoculture, crop rotations) and soil management strategies (i.e., conventional tillage, conservation agriculture).

Soil tillage methods have complex effects on physical, chemical properties of soil, which alter in turn the biological properties. Protein crops, and in particular grain legumes, possess certain characteristics particularly suitable for sustainable cropping systems and conservation agriculture, and making them functional either as cash crop or as crop residue [49]. Conservation agriculture (CA) is based on minimal soil disturbance and permanent soil cover combined with rotations [50] and in Europe, the CA is applied in regions where soil erosion mitigation and protection against land degradation are important objectives.

Also, legumes' biological fixation of atmospheric $\mathrm{N}_{2}$ can be affected by "starter- $\mathrm{N}$ " and tillage; Torabian et al. [51-53] showed that conservation tillage typically enhances nodulation and nitrogen fixation, through increased soil moisture retention and soil temperature, and increased soil microbial biomass. According Krishna [54], there are several legumes as pea, faba bean, soy bean, and forage legumes that need no fertilizer-N supply, perhaps except a starter- $\mathrm{N}$ in some locations to induce rapid rooting at seedling stage. Kitamura [55] showed that legumes preferentially use available soil nitrogen rather than fix atmospheric nitrogen. Thus, high levels of available soil nitrogen will greatly reduce the amount of nitrogen fixed by the legume. However, in low nitrogen soils, a low rate of starter-N placed away from the seed may boost seedling growth of the legume prior to the establishment of 
fully functioning nodules. On the other hand, legume-based systems improve various aspects of soil fertility, including the amount of nitrogen fixed into the soil and the high quality of the organic matter released to the soil in term of $\mathrm{C} / \mathrm{N}$ ratio [49].

Many countries already depend on conservation agriculture. The SR research results show that the grain legumes like lentil, chickpea, pea, and faba bean play a major role in conservation agriculture in Spain, Italy, and Turkey ( $96 \%$ of evidences of tillage treatments in SE).

According to Stagnari et al. [49], the expansion of ecological approaches such as conservation agriculture opens up opportunities for the use of food legumes in sustainable cropping systems. In general, conservation agriculture is an environmentally sustainable production system that can increase the incorporation of grain legumes within large and small-scale farming.

Protein crops require an adequate supply of readily available nutrients for optimum growth and yield [56].

According to Da Silva et al. [57], considerable $\mathrm{N}$ is required in grain legumes at the beginning of pod fill as the translocation of $\mathrm{N}$ from vegetative parts to the pods is intensive. Studies on soybean have shown that this $\mathrm{N}$ drain may be high enough to decrease photosynthetic activity [58], induce premature leaf senescence, and reduce root activity $[59,60]$. Nutrients supplied through leaves may supplement rapidly those transferred from stems and roots, thus avoiding early leaf senescence [61].

By means of the inoculation of rhizobia or the application of $\mathrm{N}$ fertilizer with the use of ${ }^{15} \mathrm{~N}$ labeled urea, during the late stages of growth, it was possible to enhance grain legume yields without necessarily inhibiting $\mathrm{N}_{2}$ fixation [56]. According to the screening review results, these two methods were the most frequently studied treatment on SE especially in Italy and Spain.

Since indigenous rhizobia are not always in sufficient numbers, effective enough, or compatible with the specific legume crop to stimulate biological nitrogen fixation (BNF) and increase yields, inoculation of legumes with rhizobia is an important option for enhancing BNF in crop production systems [62]. The effectiveness of BNF is affected by agro-ecological factors. For instance, poor nodulation and poor plant vigor in beans grown in soil with low extractable P led to a poor BNF [63]. The idea of applying $\mathrm{N}$ through leaves to maximize bean yield is not recent $[64,65]$. The advantage of using urea is that it facilitates the accumulation of other nutrients such as $\mathrm{Mn}^{2+}$ and permits the transport of nutrients through a more permeable cell cuticle [66].

Seed yields of high-quality protein crops like quinoa strongly respond to $\mathrm{N}$ fertilization [67]; for this reason, the main field trials carried out in Europe during last years to evaluate adaptability of different quinoa varieties were also focused on the assessment of nitrogen requirements [68].

Sowing date is one of the most important management factors affecting protein crops production and quality [69]. In a given region, the optimum sowing date depends mainly upon the timing of rainfall [70]. In most cases, delaying sowing beyond the optimum period reduces crops yields [71,72]. As a consequence, delaying sowing date can cause significant differences of environmental conditions during grain filling, usually causing grains to grow with increasing temperatures and diminishing moisture conditions $[73,74]$.

A number of studies, from our SR, has reported on the optimum sowing dates for legumes. Yield variation as a function of sowing date and sowing density ranged from 1.01 to $3.65 \mathrm{tha}^{-1}$ and from 1.45 to $2.29 \mathrm{t} \mathrm{ha}^{-1}$, respectively. Furthermore, the early winter sowing date in Spain, and March sowing date in Greece, seemed to ensure the highest response for chickpea in the southern Europe. In general, early sowing resulted in seed yield increases and there was a frequency for seed yield to decrease with delay of sowing [56]. Quinoa grown under Mediterranean conditions produce higher seed yields if sown in April compared to May [75].

In addition, the sowing density is an important factor-affecting yield of grain legumes according to many studies, from inside and outside EU [76-78]. Therefore, yield response of seed legumes to seeding rates was discussed by several authors, and a significant effect of seeding rate on seed yield was found $[79,80]$. 
Water resources in the EU and especially in Mediterranean region become more and more scarce because of high demand for water due to population growth and increasing demand for food. Climate change has also aggravated the situation because of erratic rainfall and the succession of drought years [81].

This challenge is further compounded by the severe competition for land and water from industry and urban development [82]. Such competition pushes agriculture to marginal areas, where water-limiting conditions often constrain crop productivity. In these marginal areas (e.g., semi-arid environments), water limitation and year to year fluctuations of meteorological conditions tend to be large, and these variations significantly affect food security in rain-fed systems [83].

Droughts can negatively impact the yield of most protein crops, from C4 plant (e.g., amaranth) to C3 (e.g., quinoa and legumes) [84-86]. The yield of food legumes grown in arid to semi-arid environments or drylands such as the Mediterranean (e.g., faba beans, chickpea, and lentil) is usually variable or low due to terminal droughts that characterize these areas $[87,88]$.

Currently, the economically viable approaches to support crop production under drought are still limited [89]. More importantly, it remains unclear how the impact of drought on legume production varies with legume species, regions, agroecosystems, soil texture, and drought timing.

The results of our systematic review and drought manipulation experiments across the EU region will allow to better characterize the factors that determine the magnitude of yield loss in legumes due to drought stress, which must be considered in agricultural planning to increase the resilience of legume production systems.

\section{Conclusions}

This systematic review details the setting for a large number of studies across a broad range of agronomic management, protein crops, and geographical locations.

The EU depends on imported high-protein plant products. The main reason for this is that protein crops in the EU are not competitive with the crops currently being produced. However, the competitiveness of crops can be expected to differ between regions within Europe because local conditions have a high influence on yield levels [3]. In addition to higher yield potential of cereals in Europe, farmers who grow protein crops face up to a range of agronomic challenges. The evidence from this SR confirms that protein crop yields are considered unstable, as pointed out in many studies $[10,43,90]$.

Therefore, as in most of the cultivated areas, legume yield is unstable, legume production is limited. This constraint is explained by many other external factors, such as the historical dependence to the Common Agricultural Policy measures; low level of production of processed products; competition with soybean imports from the Americas or with protein-rich byproducts derived from non-legume crops. It is also possible that European farmers are not motivated to cultivate these species on soils of good quality in appropriate environments, and that they prefer growing more profitable major crops in these environments (e.g., wheat, maize, and rapeseed).

These agronomic challenges highlight a need for research to support crop development in order to increase and stabilize yields in relation to those of other crops. To do this we should answer this question: What are the main research needs (technical, social-economic) for protein crops to be competitive?

A useful approach to achieve this aim could be represented by exchange between several regions across Europe which will also contribute to increase the profitability of EU protein crops. Sharing knowledge on the use of varieties and best practices, even worst practices, is a key to success.

Access to practical knowledge and best practices of protein crop production is required. A useful approach to achieve this aim could be represented by a meta-regression analysis of mixed effects using the relative yield as effect size estimator. An effect size estimator is an index which allows us to compare the experimental treatment mean to the control treatment mean [91] and to quantify the magnitude of a treatment's effect. Because all of the studies we used did not report any measure of 
variance, an unweighted meta-regression could be performed. The meta-regression analysis would allow to investigate the interaction between different protein-crops, European region, and agronomic management and the effect of these factors on yield response.

Supplementary Materials: The following are available online at http://www.mdpi.com/2073-4395/9/6/292/s1.

Author Contributions: Conceptualization, M.H.S.; Methodology, M.H.S. and M.A.; Formal analysis, M.H.S. and M.A.; Investigation, M.H.S.; Resources, M.H.S.; Data curation, M.H.S.; Writing—original draft preparation, M.H.S.; Writing—review and editing, M.H.S., A.M.S., C.P., and A.L.; Visualization, M.H.S.; Supervision, A.L.

Funding: This research has been undertaken as part of the PROTEIN2FOOD project. This project has received funding from the European Union's Horizon 2020 research and innovation program under grant agreement no. 635727.

Acknowledgments: We are grateful to Maurizio Buonanno (CNR-ISAFOM) for plotting the map of selected studies to be included in the systematic review.

Conflicts of Interest: The authors declare no conflict of interest.

\section{References}

1. McCarthy, E.; Stephen, N.; O'Sullivan, S.N. How to feed the world in 2050? STOA Workshop 2013, European Parliament, Brussels. Available online: https://www.europarl.europa.eu/stoa/cms/home/events/ workshops/feeding (accessed on 13 February 2019).

2. Van Gelder, J.W.; Herder, A. Soja Barometer 2012; Een Onderzoeksrapport voor de Nederlandse Sojacoalitie. Available online: https://www.bothends.org/nl/Actueel/Publicaties/Soy-Barometer-2012-English-version(accessed on 13 February 2019).

3. Bues, A.; Preißel, S.; Reckling, M.; Zander, P.; Kuhlman, K.; Topp, K.; Watson, K.; Lindström, K.; Stoddard, FL.; Murphy-Bokern, D. Protein crops and their role in Europe. In The Environmental Role of Protein Crops in the New Common Agricultural Policy; Study 2013; European Union: Brussels, Belgium, 2013; Available online: http://www.europarl.europa.eu/studies (accessed on 24 June 2018).

4. Laaninen, T. Imports of GM Food and Feed: Right of Member States to Opt Out 2015; European Parliamentary Research Service: Brussels, Belgium, 2015; Available online: https://www.europarl.europa.eu/etudes/BRIE (accessed on 26 April 2019).

5. Halford, N.G. Legislation governing genetically modified and genome-edited crops in Europe: The need for change. J. Sci. Food Agric. 2019, 99, 8-12. [CrossRef] [PubMed]

6. Häusling, M. The EU Protein Deficit: What Solution for a Long-Standing Problem? 2010/2111 (INI); Committee on Agricultural and Rural Development, European Parliament: Brussels, Belgium, 2011.

7. De Visser, C. Starting paper Protein Crops. In EIP-AGRI Focus Group Protein Crops: Final Report 2013; European Commission: Brussels, Belgium, 2013; Available online: https:/ec.europa.eu/eip/agriculture/en/publications/ eip-agri-focus-group-protein-crops-final-report (accessed on 24 June 2018).

8. FAOstat. Statistics Database of the Food and Agriculture Organization of the United Nations 2017. Available online: http://www.fao.org/statistics/databases/en/ (accessed on 26 April 2019).

9. Bazile, D.; Jacobsen, S.E.; Verniau, A. The global expansion of quinoa: Trends and limits. Front. Plant Sci. Sect. Crop Sci. Hortic. 2016, 7, 622. [CrossRef] [PubMed]

10. Von Richthofen, J.-S.; Pahl, H.; Bouttet, D.; Casta, P.; Cartrysse, C.; Charles, R.; Lafarga, A. What do European farmers think about grain legumes? Grain Legume 2006, 45, 14-15. Available online: http: //www.ias.csic.es/grainlegumesmagazine/ (accessed on 25 June 2018).

11. Voisin, A.S.; Guéguen, J.; Huyghe, C.; Jeuffroy, M.H.; Magrini, M.B.; Meynard, J.M.; Mougel, C.; Pellerin, S.; Pelzer, E. Legumes for feed, food, biomaterials and bioenergy in Europe: A review. Agron. Sustain. Dev. 2014, 34, 361-380. [CrossRef]

12. Stoddard, F.L. The Case Studies of Participant Expertise in Legume Futures; Legume Futures Report 1.2. 2013. Available online: http://www.legumefutures.de/ (accessed on 13 February 2019).

13. Sargeant, J.M.; Rajic, A.; Read, S.; Ohlsson, A. The process of systematic review and its application in agri-food public-health. Prev. Vet. Med. 2006, 75, 141-151. [CrossRef]

14. Sargeant, J.M.; O'Connor, AM. Introduction to systematic reviews in animal agriculture and veterinary medicine. Zoonoses Public Health 2014, 61, 3-9. [CrossRef] [PubMed] 
15. Cuccurullo, C.; Aria, M.; And Sarto, F. Foundations and trends in performance management. A twenty-five years bibliometric analysis in business and public administration domains. Scientometrics 2016, 108, 595-611. [CrossRef]

16. Curtis, P.S.; Wang, X.Z. A meta-analysis of elevated $\mathrm{CO}_{2}$ effects on woody plant mass, from and physiology. Ecologia 1998, 113, 299-313.

17. Rohatgi, A. WebPlotDigitizer 2011. Available online: http://arohatgi.info/WebPlotDigitizer/app3_12/ (accessed on 30 December 2017).

18. Lê, S.; Josse, J.; Husson, F. FactoMineR: An R package for multivariate analysis. J. Stat. Softw. 2008, 25, 1-18. [CrossRef]

19. Greenacre, M.; Hastie, T. The geometric interpretation of correspondence analysis. J. Am. Stat. Assoc. 1987, 82, 437-447. [CrossRef]

20. Benzécri, J.-P. Sur le calcul des taux d'inertie dans l'analyse d'un questionnaire: Addendum et Erratum à (Bin. Mult.). Les Cahiers de l'Analyse des Données 1979, 4, 377-378.

21. Kostov, B.; Bécue-Bertaut, M.; Husson, F. “Correspondence Analysis on Generalised Aggregated Lexical Tables (CA-GALT)" in the FactoMineR Package. R. J. 2015, 7, 109-117. [CrossRef]

22. R Core Team. R: A Language and Environment for Statistical Computing; R Foundation for Statistical Computing: Vienna, Austria, 2013.

23. Giambalvo, D.; Ruisi, P.; Saia, S.; Di Miceli, G.; Frenda, A.A.; Amato, G. Faba bean grain yield, N2 fixation, and weed infestation in a long-term tillage experiment under rainfed Mediterranean conditions. Plant Soil 2012, 360, 215-227. [CrossRef]

24. López-Bellido, R.J.; Lopez-Bellido, L.; Lopez-Bellido, F.J.; Castillo, J.E. Faba Bean (Vicia faba L.) Response to Tillage and Soil Residual Nitrogen in a Continuous Rotation with Wheat (Triticum aestivum L.) under Rainfed Mediterranean Conditions. Agron. J. 2003, 95, 1253-1261.

25. López -Bellido, L.; Lopez-Bellido, R.J.; Castillo, J.E.; Lopez-Bellido, F.J. Chickpea response to tillage and soil residual nitrogen in a continuous rotation with wheat. I. Biomass and seed yield. Field Crop. Res. 2004, 88, 191-200. [CrossRef]

26. FAOstat. Statistics Database of the Food and Agriculture Organization of the United Nations 2016. Available online: http://www.fao.org/statistics/databases/en/ (accessed on 30 October 2016).

27. Watson, C.A.; Reckling, M.; Preisse, S.; Bachinger, J.; Bergkvist, G.; Kuhlman, T.; Lindström, K.; Nemecek, T.; Topp, C.F.E.; Vanhatalo, A.; et al. Chapter Four_Grain Legume Production and Use in European Agricultural Systems. Advances in Agronomy, 1st ed.; Sparks, D.L., Ed.; Zoe Kruze: Cambridge, MA, USA, 2017; Volume 144, pp. 235-303.

28. Van Hoye, I. Growing Protein Crops Has a Profitable Future. Available online: https://ec.europa.eu/eip/ agriculture/sites/agri-eip/files/2015-press20150611-ws_protein_crops_fin.pdf (accessed on 24 June 2018).

29. Reckling, M.; Döring, T.F.; Bergkvist, G.; Stoddard, F.L.; Watson, C.A.; Seddig, S.; Chmielewski, F.M.; Bachinger, J. Grain legume yields are as stable as other spring crops in long-term experiments across northern Europe. Agron. Sustain. Dev. 2018, 38, 63. [CrossRef] [PubMed]

30. Stoddard, F.L.; Balko, C.; Erskine, W.; Khan, H.R.; Link, W.; Sarker, A. Screening techniques and sources of resistance to abiotic stresses in cool-season food legumes. Euphytica 2006, 147, 167-186. [CrossRef]

31. De Visser, C. Protein Crops. Available online: https://ec.europa.eu/eip/agriculture/sites/agri-eip/files/fg2 protein_crops_starting_paper_2013_en.pdf (accessed on 24 June 2018).

32. Malezieux, E.; Crozat, Y.; Dupraz, C.; Laurans, M.; Makowski, D.; Ozier-Lafontaine, H.; Rapidel, B.; de Tourdonnet, S.; Valantin-Morison, M. Mixing plant species in cropping systems: Concepts, tools and models. A review. Agron. Sustain. Dev. 2009, 29, 43-62. [CrossRef]

33. Taylor, B.R.; Cormack, W.F. Choice of Cereal and Pulse Species and Varieties. In Organic Cereals and Pulses; Papers presented at conferences held at the Heriot-Watt University, Edinburgh, and at Cranfield University Silsoe Campus, Bedfordshire, 6 and 9 November 2001 (pp. 9-28); Chalcombe Publications: Southampton, UK, 2002.

34. EIP-AGRI. How to make protein crops profitable in the EU? 2015, Workshop. Budapest. Available online: https://ec.europa.eu/eip/agriculture/sites/agri-eip/files/field_event_attachments/report_ws_ proteincrops_final_13022015.pdf (accessed on 25 June 2018).

35. Lucas, M.M.; Stoddard, F.L.; Annicchiarico, P.; Frías, J.; Martínez-Villaluenga, C.; Sussmann, D.; Pueyo, J.J. The future of lupin as a protein crop in Europe. Front. Plant Sci. 2015, 6, 705. [CrossRef] 
36. Gresta, F.; Wink, M.; Prins, U.; Abberton, M.; Capraro, J.; Scarafoni, A.; Hill, G. Lupins. European cropping systems. In Legumes in Cropping Systems; CABI: Oxfordshire, UK, 2017; pp. 88-108.

37. Yeheyis, L.; Kijora, C.; Melaku, S.; Girma, A.; Peters, K.J. White lupin (Lupinus albus L.), the neglected multipurpose crop: Its production and utilization in the mixed crop-livestock farming system. Livest. Res. Rural Dev. 2010, 22, 74.

38. Stoddard, F.; Hovinen, S.; Kontturi, M.; Lindstrom, K.; Nykanen, A. Legumes in Finnish agriculture: History, present status and future prospects. Agric. Food Sci. 2009, 18, 191-205. [CrossRef]

39. Annicchiarico, P.; Iannucci, A. Breeding strategy for faba bean in southern Europe based on cultivar responses across climatically contrasting environments. Crop Sci. 2008, 48, 983-991. [CrossRef]

40. Lizarazo, C.I.; Lampi, A.M.; Liu, J.; Sontag-Strohm, T.; Piironen, V.; Stoddard, F.L. Nutritive quality and protein production from grain legumes in a boreal climate. J. Sci. Food Agric. 2015, 95, 2053-2064. [CrossRef] [PubMed]

41. Corre-Hellou, G.; Crozat, Y. $\mathrm{N}_{2}$ fixation and $\mathrm{N}$ supply in organic pea (Pisum sativum L.) cropping systems as affected by weeds and peaweevil (Sitona lineatus L.). Eur. J. Agron. 2005, 22, 449-458. [CrossRef]

42. Jensen, E.S.; Peoples, M.B.; Hauggaard-Nielsen, H. Faba bean in cropping systems. Field Crops Res. 2010, 115, 203-216. [CrossRef]

43. Flores, F.; Nadal, S.; Solis, I.; Winkler, J.; Sass, O.; Stoddard, F.L.; Link, W.; Raffiot, B.; Muel, F.; Rubiales, D. Faba bean adaptation to autumn sowing under European climates. Agron. Sustain. Dev. 2012, 32, 727-734. [CrossRef]

44. Cernay, C.; Ben-Ari, T.; Pelzer, E.; Meynard, J.-M.; Makowski, D. Estimating variability in grain legume yields across Europe and the Americas. Sci. Rep. 2015, 5, 11171. [CrossRef]

45. Christopher, S.F.; Lal, R. Nitrogen management affects carbon sequestration in North American cropland soils. Crit. Rev. Plant Sci. 2007, 26, 45-64. [CrossRef]

46. Soussana, J.F.; Loiseau, P.; Vuichard, N.; Ceschia, E.; Balesdent, J.; Chevallier, T.; Arrouays, D. Carbon cycling and sequestration opportunities in temperate grasslands. Soil Use Manag. 2004, 20, 219-330. [CrossRef]

47. Freibauer, A.; Rounsevell, MD.; Smith, P.; Verhagen, J. Carbon sequestration in the agricultural soils of Europe. Geoderma. 2004, 122, 1-23. [CrossRef]

48. Jensen, E.S.; Peoples, M.B.; Boddey, R.M.; Gresshoff, P.M.; Hauggaard-Nielsen, H.; Alves, B.J.; Morrison, M.J. Legumes for mitigation of climate change and the provision of feedstock for biofuels and biorefineries. A review. Agron. Sustain. Dev. 2012, 32, 329-364. [CrossRef]

49. Stagnari, F.; Maggio, A.; Galieni, A.; Pisante, M. Multiple benefits of legumes for agriculture sustainability: An overview. Chem. Biol. Technol. Agric. 2017, 4, 1-13. [CrossRef]

50. Hobbs, P.R.; Sayre, K.; Gupta, R. The role of conservation agriculture in sustainable agriculture. Philos. Trans. R. Soc. Lond. Ser. B 2008, 363, 543-555. [CrossRef] [PubMed]

51. Torabian, S.; Farhangi-Abriz, S.; Denton, M.D. Do tillage systems influence nitrogen fixation in legumes? A review. Soil Tillage Res. 2019, 185, 113-121. [CrossRef]

52. Okoth, J.O.; Mungai, N.W.; Ouma, J.P.; Baijukya, F.P. Effect of tillage on biological nitrogen fixation and yield of soybean ('Glycine max L. Merril') varieties. Aust. J. Crop Sci. 2014, 8, 1140.

53. Wiraguna, E. Enhancement of Fixation Nitrogen in Food Legumes. J. Agric. Stud. 2016, 4. [CrossRef]

54. Krishna, K.R. Agricultural Prairies: Natural Resources and Crop Productivity; CRC Press: Boca Raton, FL, USA, 2015; 514p.

55. Kitamura, Y. Use of starter nitrogen for establishing tropical legume-grass pasture. Jarq-Japan Agric. Res. Q. 1982, 15, 253-260.

56. Turk, M.A.; Tawaha, A.R.M. Impact of seeding rate, seeding date, rate and method of phosphorus application in faba bean (Vicia faba L. minor) in the absence of moisture stress. Biotechnol. Agron. Soc. Environ. 2002, 6, 171-178.

57. Da Silva, P.M.; Tsai, S.M.; Bonetti, R. Response to Inoculation and N Fertilization for Increased Yield and Biological Nitrogen Fixation of Common Bean (Phaseolus vulgaris L.). In Enhancement of Biological Nitrogen Fixation of Common Bean in Latin America; Springer: Dordrecht, The Netherlands, 1993; pp. 123-130.

58. Dunphy, E.J.; Hanway, J.J. Water-soluble carbohydrate accumulation in soybean plants. Agron. J. 1976, 68, 697-700. [CrossRef]

59. Harper, J.E. Soil and symbiotic nitrogen requirements for optimum soybean production. Crop Sci. 1974, 14, 255-260. [CrossRef] 
60. Garcia, L.; Hanway, J.J. Foliar Fertilization of Soybeans During the Seed-filling Period 1. Agron. J. 1976, 68, 653-657. [CrossRef]

61. Frith, G.J.T.; Dalling, M.J. The Role of Peptide Hydrolases in Leaf Senescence. In Senescence in Plants; K V Thimann: Boca Raton, FL, USA, 1980; pp. 117-130.

62. Giller, K.E. Nitrogen Fixation in Tropical Cropping Systems, 2nd ed.; CABI Publishing: Wallingford, UK, 2001; pp. 271-297.

63. Amijee, F.; Giller, K.E. Environmental constraints to nodulation and nitrogen fixation of Phaseolus vulgaris L. in Tanzania, I. A survey of soil fertility, root nodulation and multilocational responses to rhizobium inoculation. Afr. J. Crop Sci. 1998, 6, 159-169. [CrossRef]

64. Miysaka, S.; Freire, E.S.; Mascarenhas, H.S. Modo e epoca de aplicacao de nitrogenio na cultura do feijoeiro. Bragantia 1963, 22, 511-519. [CrossRef]

65. Muraoka, T.; Neptune, A.M.L. Efeito da aplicacao foliar de polifosfato, superfosfato, ureia e yogen na producao de feijoeiro (Phaseolus vulgaris L.). Rev. Bras. Cienc. Solo 1978, 2, 51-55.

66. Malavolta, E. Elementos de Nutricion de Plantas; Ceres: Primavera do Leste, Brazil, 1981; pp. 80-94.

67. Kaul, H.P.; Kruse, M.; Aufhammer, W. Yield and nitrogen utilization efficiency of the pseudocereals amaranth, quinoa, and buckwheat under differing nitrogen fertilization. Eur. J. Agron. 2005, 22, 95-100.

68. Razzaghi, F.; Plauborg, F.; Jacobsen, S.E.; Jensen, C.R.; Andersen, M.N. Effect of nitrogen and water availability of three soil types on yield, radiation use efficiency and evapotranspiration in field-grown quinoa. Agr. Water Manag. 2018, 109, 20-29. [CrossRef]

69. McLeod, J.G.; Campbell, C.A.; Dyck, F.B.; Vera, C.L. Optimum seeding dates of winter wheat in southwestern Saskatchewan. Agron. J. 1992, 84, 86-90. [CrossRef]

70. Jackson, L.F.; Dubcovsky, J.; Gallagher, L.W.; Wennig, R.L.; Heaton, J.; Vogt, H.; Gibbs, L.K.; Kirby, D.; Canevari, M.; Carlson, H.; et al. Regional Barley and Common and Durum Wheat Performance Tests in California 2000; University of California, Agronomy Progress Report No. 272. Available online: http://agric.ucdavis.edu/crops/cereals/2000/oct2000.htm (accessed on 25 June 2018).

71. Anderson, W.K.; Smith, W.R. Yield advantage of two semi-dwarf compared with two tall wheats depends on sowing time. Aust. J. Agric. Res. 1990, 41, 811-826. [CrossRef]

72. Bassu, S.; Asseng, S.; Motzo, R.; Giunta, F. Optimising sowing date of durum wheat in a variable Mediterranean environment. Field Crops Res. 2009, 111, 109-118. [CrossRef]

73. Panozzo, J.F.; Eagles, H.A. Rate and duration of grain filling and grain nitrogen accumulation of wheat cultivars grown in different environments. Aust. J. Agric. Res. 1999, 50, 1007-1015. [CrossRef]

74. Subedi, K.D.; Ma, B.L.; Xue, A.G. Planting date and nitrogen effects on grain yield and protein content of spring wheat. Crop Sci. 2007, 47, 36-44. [CrossRef]

75. Pulvento, C.; Riccardi, M.; Lavini, A.; d'Andria, R.; Iafelice, G.; Marconi, E. Field trial evaluation of two chenopodium quinoa genotypes grown under rain-fed conditions in a typical Mediterranean environment in South Italy. J. Agron. Crop Sci. 2010, 196, 407-411. [CrossRef]

76. Tawaha, A.M.; El-Shatnawi, M.K.J. Response of lentil (Lens culinaris Medik) to plant density, sowing date, phosphorus fertilization and ethephon application in the absence of moisture stress. J Agron. Crop Sci. 2003, 189, 1-6.

77. Martin, I.; Tenoria, J.L.; Ayerbe, L. Yield growth and water use of conventional and semi leafless peas in semi-arid environments. Crop Sci. 1994, 34, 1576-1583. [CrossRef]

78. Noffsinger, L.S.; Santen, E. Yield and yield components of spring-sown white lupin in the southeastern USA. Agron. J. 1995, 87, 493-497. [CrossRef]

79. McEwen, J.; Yeoman, D.P.; Moffitt, R. Effect of seed rates, sowing dates and methods of sowing on autumn sown field beans (Vicia faba L.). J. Agric. Sci. Camb. 1988, 110, 345-352. [CrossRef]

80. Tawaha, A.M.; Turk, M.A. Crop-weed competition studies in faba bean (Vicia faba L.) under rainfed conditions. Acta Agron. Hung. 2001, 49, 299-303. [CrossRef]

81. Hirich, A. Effects of Deficit Irrigation using Treated Wastewater and Irrigation with Saline Water on Legumes, Corn and Quinoa Crops. Ph.D. Thesis, Institut Agronomique et vétérinaire Hassan II, Morocco, 2014.

82. Postel, S.L. Entering an Era of Water Scarcity: The Challenges Ahead. Ecol. Appl. 2000, 10, 941-948. [CrossRef]

83. Daryanto, S.; Wang, L.; Jacinthe, P.-A. Global Synthesis of Drought Effects on Food Legume Production. PLoS ONE 2015, 10, 1-16. [CrossRef] 
84. Olesen, J.E.; Trnka, M.; Kersebaum, K.C.; Skjelvag, A.O.; Seguin, B.; Peltonen-Sainio, P.; Rossi, F.; Kozyra, J.; Micale, F. Impacts and adaptation of European crop production systems to climate change. Eur. J. Agron. 2011, 34, 96-112. [CrossRef]

85. Pandey, R.K.; Herrera, W.A.T.; Pendleton, J.W. Drought response of grain legumes under irrigation gradient: 1. Yield and yield components. Agron. J. 1984, 76, 549-553. [CrossRef]

86. Peterson, P.R.; Sheaffer, C.C.; Hall, M.H. Drought effects on perennial forage legume yield and quality. Agron. J. 1992, 84, 774-779. [CrossRef]

87. Karou, M.; Oweis, T. Water and land productivities of wheat and food legumes with deficit supplemental irrigation in a Mediterranean environment. Agric. Water Manag. 2012, 107, 94-103. [CrossRef]

88. Mafakheri, A.; Siosemardeh, A.; Bahramnejad, B.; Struik, PC.; Sohrabi, E. Effect of drought stress on yield, proline and chlorophyll contents in three chickpea cultivars. Aust. J. Crops Sci. 2010, 4, 580-585.

89. Li, F.; Cook, S.; Geballe, GT.; Burch, W.R., Jr. Rainwater Harvesting Agriculture: An Integrated System for Water Management on Rainfed Land in China's Semiarid Areas. Ambio 2000, 29, 477-483. [CrossRef]

90. Sass, O. Marktsituation und züchterische Aktivitäten bei Ackerbohnen und Körnererbsen in der EU (Market situation and breeding input in faba bean and field pea in the EU). J. für Kulturpflanzen 2009, 61, 306-308.

91. Osenberg, C.W.; Sarnelle, O.; Cooper, S.D.; Holt, R.D. Resolving ecological questions through meta-analysis: Goals, metrics, and models. Ecology 1999, 80, 1105-1117. [CrossRef]

(C) 2019 by the authors. Licensee MDPI, Basel, Switzerland. This article is an open access article distributed under the terms and conditions of the Creative Commons Attribution (CC BY) license (http://creativecommons.org/licenses/by/4.0/). 